\title{
CCN2 (Connective Tissue Growth Factor) is essential for extracellular matrix production and integrin signaling in chondrocytes
}

\author{
Takashi Nishida • Harumi Kawaki • Ruth M. Baxter • \\ R. Andrea DeYoung • Masaharu Takigawa • \\ Karen M. Lyons
}

Received: 27 February 2007 / Accepted: 4 April 2007 / Published online: 16 May 2007

(C) The International CCN Society 2007

\begin{abstract}
The matricellular protein $\mathrm{CCN} 2$ (Connective Tissue Growth Factor; CTGF) is an essential mediator of ECM composition, as revealed through analysis of $C \mathrm{cn} 2$ deficient mice. These die at birth due to complications arising from impaired endochondral ossification. However, the mechanism(s) by which CCN2 mediates its effects in cartilage are unclear. We investigated these mechanisms using $\mathrm{Ccn} 2^{-/-}$chondrocytes. Expression of type II collagen and aggrecan were decreased in $\mathrm{Ccn} 2^{-/}$chondrocytes, confirming a defect in ECM production. $\mathrm{Ccn} 2^{-/-}$chondrocytes also exhibited impaired DNA synthesis and reduced adhesion to fibronectin. This latter defect is associated with decreased expression of $\alpha 5$ integrin. Moreover, $\mathrm{CCN} 2$ can bind to integrin $\alpha 5 \beta 1$ in chondrocytes and can stimulate increased expression of integrin $\alpha 5$. Consistent with an essential role for CCN2 as a ligand for integrins, immuno-
\end{abstract}

T. Nishida $\cdot$ R. M. Baxter $\cdot$ R. A. DeYoung $\cdot$ K. M. Lyons $(\triangle)$

Department of Orthopaedic Surgery,

David Geffen School of Medicine at UCLA,

2641 MacDonald Research Laboratories,

675 Charles E. Young Dr. South,

Los Angeles, CA 90095, USA

e-mail: klyons@mednet.ucla.edu

\section{K. M. Lyons}

Department of Molecular, Cell, and Developmental Biology,

University of California, Los Angeles,

2641 MacDonald Research Laboratories,

675 Charles E. Young Dr. South,

Los Angeles, CA 90095, USA

T. Nishida $\cdot$ H. Kawaki $\cdot$ M. Takigawa

Department of Biochemistry and Molecular Dentistry,

Okayama University Graduate School of Medicine,

Dentistry and Pharmaceutical Sciences,

2-5-1 Shikata-cho, Okayama 700-8525, Japan fluorescence and Western blot analysis revealed that levels of focal adhesion kinase (FAK) and extracellular signalregulated kinase (ERK)1/2 phosphorylation were reduced in $\mathrm{Ccn}^{-/-}$chondrocytes. These findings argue that $\mathrm{CCN} 2$ exerts major effects in chondrocytes through its ability to (1) regulate ECM production and integrin $\alpha 5$ expression, (2) engage integrins and (3) activate integrin-mediated signaling pathways.

Keywords Connective tissue growth factor/CCN2 . Integrin $\alpha 5$. Extracellular signal-regulated kinase (ERK)1/2 . Focal adhesion kinase (FAK) · Chondrocyte $\cdot$ Fibronectin

$\begin{array}{ll}\text { Abbreviations } \\ \text { bp } & \text { base pairs } \\ \text { E } & \text { embryonic day } \\ \text { ECM } & \text { extracellular matrix } \\ \text { ERK1/2 } & \text { extracellular signal-regulated kinase } 1 / 2 \\ \text { FAK } & \text { focal adhesion kinase } \\ \text { FN } & \text { fibronectin } \\ \text { NP 40 } & \text { Nonidet P-40 } \\ \text { rCCN2 } & \text { recombinant CCN2 protein } \\ \text { VN } & \text { vitronectin } \\ \text { WT } & \text { wild type }\end{array}$

\section{Introduction}

Interactions of cells with the extracellular matrix (ECM) play essential roles in morphogenesis and repair (Ekblom et al. 1986). CCN proteins are matricellular molecules that have important roles in these processes (Lau and Lam 1999; Takigawa 2003; Perbal 2004; Perbal and Takigawa 2005; Rachfal and Brigstock 2005; Kubota and Takigawa 2007). 
CCN2 (Connective tissue growth factor (CTGF)) is a cysteine-rich, ECM-associated, heparin-binding protein, with the characteristic structure of $\mathrm{CCN}$ proteins: an $\mathrm{N}$ terminal secretory signal, followed by four modular domains (Brigstock 2003).

$\mathrm{CCN} 2$ is a major inducer of ECM production in fibrotic disease (Leask and Abraham 2004), but its role in normal tissues is less well understood. CCN2 is highly expressed in cartilage and endothelial cells in vivo (Nakanishi et al. 2000; Friedrichsen et al. 2003; Ivkovic et al. 2003). Previously, we reported that recombinant CCN2 (rCCN2) promotes the proliferation and differentiation of chondrocytes and osteoblasts (Nakanishi et al. 2000). In order to test the physiological relevance of these activities, we generated Ccn2-deficient mice (Ivkovic et al. 2003). These die soon after birth, in part as a result of severe skeletal abnormalities associated with impaired chondrocyte proliferation and ECM expression (Ivkovic et al. 2003). The hypertrophic zones of mutants are enlarged, due to defective remodeling of the cartilage ECM by chondroclasts/osteoclasts, impaired invasion by blood vessels, and subsequent inability to support the formation of an osteoid matrix by osteoblasts (Ivkovic et al. 2003). These and other findings indicate that CCN2 promotes endochondral ossification by enhancing the proliferation and maturation of chondrocytes, and the survival of invading endothelial cells (Nakanishi et al. 2000; Ivkovic et al. 2003; Shimo et al. 1999).

A second member of the $\mathrm{CCN}$ family, CCN6, is also essential for chondrocyte function. Homozygosity for lossof-function mutations in Ccn6 leads to progressive pseudorheumatoid dysplasia in humans (Hurvitz et al. 1999). This disease is a severe form of childhood-onset arthritis, but nothing is known about the role of CCN6 in normal cartilage. CCN1 may also have essential functions in chondrogenesis. Although $\mathrm{Ccnl}^{-/}$mutants die too early to examine skeletal development, CCN1 stimulates chondrocyte proliferation and ECM accumulation in vitro (Wong et al. 1997; Mo et al. 2002). Given that multiple members of the $\mathrm{CCN}$ family have essential functions in chondrogenesis, understanding the mechanisms by which these proteins function is an important issue.

CCN2 functions as a ligand for integrins in vitro (Lau and Lam 1999; Babic et al. 1999; Leu et al. 2003; Chen et al. 2004; Gao and Brigstock 2004; Hoshijima et al. 2006; Tong and Brigstock 2006). Integrins play a fundamental role in chondrocyte survival, proliferation and differentiation (Hynes 2002; Loeser 2002). Work from a number of laboratories has documented the presence of $\alpha 1 \beta 1, \alpha 5 \beta 1$, $\alpha 6 \beta 1$, and $\alpha \mathrm{v} \beta 5$ integrins in intact cartilage (Loeser 2002). Of these, $\alpha 5 \beta 1$ is thought to be the most abundant of the $\beta 1$-containing integrins in fetal cartilage (Häusler et al.
2002). $\alpha 5 \beta 1$ integrin plays multiple roles in chondrocyte survival and function (Enomoto-Iwamoto et al. 1997; Salter et al. 2001; Pulai et al. 2002; Chen et al. 2005), and cartilagespecific $\beta 1$-integrin-deficient mice exhibit profoundly abnormal growth plate structure (Aszodi et al. 2003). A role for $\alpha 5 \beta 1$ integrin in the decision chondrocytes make between endochondral ossification and joint formation has also been suggested (Garciadiego-Cázares et al. 2004). The collagen binding integrins $\alpha 1 \beta 1$ and $\alpha 10 \beta 1$ are also expressed in chondrocytes (Camper et al. 1998; Zemmyo et al. 2003). Integrin $\alpha 1^{-/}$mice are prone to osteoarthritis (Zemmyo et al. 2003) and exhibit impaired cartilage formation during fracture healing (Ekholm et al. 2002). Mice deficient in $\alpha 10$ have only minor defects in cartilage (Bengtsson et al. 2005). Chondrocytes also express integrin $\alpha 2$ (Kim et al. 2003; Lahiji et al. 2004), but no skeletal defects have been reported in integrin $\alpha 2^{-/-}$mice (Chen et al. 2002; Holtkötter et al. 2002). In summary, loss of function studies reveals roles for integrins $\alpha 1, \alpha 5, \alpha 10$, and $\beta 1$ in intact cartilage, and $\alpha 5 \beta 1$ is a key regulator of multiple aspects of chondrocyte behavior.

We previously reported that $C c n 2^{-/}$fibroblasts exhibit impaired adhesive signaling and defective adhesion to fibronectin, and that CCN2 is a ligand for $\alpha 5 \beta 1$ integrin in fibroblasts (Chen et al. 2004). CCN2 also regulates $\alpha 5 \beta 1$ integrin expression in rat fibroblasts (Frazier et al. 1996) and human mesangial cells in vitro (Weston et al. 2003). These studies raise the possibility that CCN2 is an essential ligand for integrins in chondrocytes, and/or regulates integrin expression. We used $\mathrm{Ccn}^{-/}$chondrocytes to examine these possibilities and their potential relevance to the chondrodysplasia observed in $\mathrm{Ccn} 2^{-/-}$mice.

\section{Materials and methods}

\section{Reagents}

Dulbecco's modified Eagle Medium (DMEM) and Minimum Essential ( $\alpha$ MEM) Medium Alpha $(\alpha \mathrm{MEM})$ were purchased from Invitrogen (Grand Island, NY); fetal bovine serum (FBS) was from Omega Scientific (Tarzana, CA). Plastic dishes and plates were obtained from BectonDickinson (Frabkin Lakes, NJ). Isotopes were from ICN Biomedicals (Aurora, $\mathrm{OH}$ ) and PerkinElmer, (Boston, MA). Trizol reagent was from Invitrogen; X-ray films were from Kodak (Rochester, NY). Anti-ERK1/2, anti-phosphoERK1/2, and anti-phoshpho-MEK1/2 were from Cell Signaling Technology (Beverly, MA); anti-FAK, antiphospho-FAK, anti-integrin $\alpha 5 \beta 1$ for immunoprecipitation (MAB1969), and anti-integrin $\alpha 5$ for Western blotting (AB1921) and anti-vimentin were from Chemicon 
(Temecula, CA), anti-aggrecan was from Abcam (Cambridge, MA); anti-collagen type II was from Cosmo Bio (Tokyo, Japan); anti- $\beta$-actin was from Sigma (St Louis, MO); antiphospho-tyrosine was from Zymed (San Francisco, CA). Alexa fluor conjugated phalloidin was from Molecular Probes (Eugene, OR). Anti-CTGF/CCN2 serum was as described previously (Nakanishi et al. 2000). Fibronectin (FN) and vitronectin $(\mathrm{VN})$ were from Sigma. rCCN2 was prepared as described (Asano et al. 2005).

\section{Isolation of chondrocytes}

Primary cultures of chondrocytes isolated from the ventral half of the rib cage of embryos were prepared as described previously (Lefebvre et al. 1994). Briefly, rib cages and sterna were dissected from E18.5 embryos, rinsed in phosphate-buffered saline (PBS), and incubated at $37^{\circ} \mathrm{C}$ for $1 \mathrm{~h}$ in $2 \mathrm{mg} / \mathrm{ml}$ pronase $\mathrm{E}$ (Sigma) in PBS, rinsed again with PBS, and then incubated with bacterial collagenase ( $3 \mathrm{mg} / \mathrm{ml}$ : collagenase D; Sigma) in DMEM at $37^{\circ} \mathrm{C}$ under $7.5 \% \mathrm{CO}_{2}$ for $1 \mathrm{~h}$ until soft tissues detached from the cartilage after gentle titration. The cartilage was then further digested with collagenase $\mathrm{D}$ for $2 \mathrm{~h}$. Residual bony parts were discarded. The remaining cell suspension was filtered through a 70- $\mu \mathrm{m}$ cell strainer (Becton Dickinson) and rinsed in $\alpha \mathrm{MEM}$ containing $10 \%$ serum. The isolated chondrocytes were seeded at a density of $1 \times 10^{5}$ cells $/ \mathrm{cm}^{2}$ into 6-well multiplates in $\alpha \mathrm{MEM}$ containing $10 \% \mathrm{FBS}$, and were then cultured at $37^{\circ} \mathrm{C}$ under $5 \% \mathrm{CO}_{2}$. Cells derived from each embryo were plated out independently, and tail samples were collected for genotyping.

\section{Adhesion assays}

Tissue culture plates (96-well multiplates) were coated with bovine serum albumin (BSA), FN, or $\mathrm{VN}$ by incubation overnight at $37^{\circ} \mathrm{C}$ in $10 \mu \mathrm{l}$ of PBS containing $5 \mu \mathrm{g}$ of the protein. The coated plates were then blocked with $1 \% \mathrm{BSA}$ for $1 \mathrm{~h}$ at $37^{\circ} \mathrm{C}$, and washed with $\mathrm{PBS}$. For the adhesion assay in Fig. 4c, 96-well plates coated with rCCN2 $(5 \mu \mathrm{g} /$ well) overnight at $37^{\circ} \mathrm{C}$. The coated plates were then blocked with a 1:10 dilution of anti- $\alpha 5$ integrin antibody (AB1921, Chemicon) or normal rabbit anti-serum for $1 \mathrm{~h}$ at $37^{\circ} \mathrm{C}$, and washed with PBS. First passage mouse chondrocytes were inoculated at a density of $5 \times 10^{4} /$ well and maintained in $\alpha \mathrm{MEM}$ containing 10\% FBS. After $60 \mathrm{~min}$, cultures were washed five times with PBS, fixed in $3.5 \%$ formaldehyde for $30 \mathrm{~min}$, and stained with $0.5 \%$ crystal violet solution (J.T. Baker Chemical, Phillipsburg, NJ) for $30 \mathrm{~min}$. Chondrocyte adhesion was quantified by dye extraction and measurement of absorbance at $550 \mathrm{~nm}$.
Northern blot analysis

Total RNA was prepared using Trizol reagent (Invitrogen). Ten $\mu \mathrm{g}$ of total RNA was subjected to electrophoresis on a $1 \%$ formaldehyde-agarose gel and transferred onto Hybond-N+filters (Amersham Pharmacia Biotech). Northern blot analysis was performed as described previously (Nishida et al. 2000, 2002). Oligo-labeled probes for mouse Ccn2, and Collagen type II (Col2A1) were used as described (Nishida et al. 2002); a probe for mouse aggrecan was amplified using the following gene-specific primers: (Gen Bank accession no. NM_007424; expected size; 197 bp), forward cggtaccctacagagacacttcaaga and reverse gtgaccctggaacttggt ccaccc.

Real-time reverse transcriptase (RT)-PCR analysis

Quantitative real-time polymerase chain reaction (PCR) was performed by using a LightCycler (Roche; Mannheim, Germany). The primer sequences were as follows: integrin $\alpha 1$ (NM_001033228 expected size 513 bp) forward ttctgatgtcagccetacatt and reverse atagctatggaaaatcgetgaa integrin $\alpha 2$ (NM_008396 expected size 244 bp) forward tgctggctgaaagaccttcacatg and reverse gataa ccctgtcggtacttct; integrin $\alpha 5$ (NM_010577; expected size; $544 \mathrm{bp)}$ forward agcgcatctctcaccatctt and reverse tcaggtt cagtgcgttcttgt; integrin $\alpha 10$ (XM_925721; expected size; 592 bp) forward tggagtctctctccatcc and reverse tcgatgaa cagtcttcctaccagc; integrin $\beta 1$ (NM_010578; expected size; $451 \mathrm{bp}$ ) forward tgttcagtgcagagcettca and reverse cctca tacttcggattgacc; and GAPDH (NM_062046.3; expected size; $171 \mathrm{bp})$ forward acc-aggtggtctcctctgacttcaa and reverse tactccttggaggccatgt-ggg. forward accaggtggtctc ctctgacttcaa and reverse tactccttggaggccatgtggg. Total RNA was reverse-transcribed to cDNA with SuperScript ${ }^{\mathrm{TM}}$ III First-Strand Synthesis System for RT-PCR (Invitrogen). Amplification reactions were performed with a $\mathrm{SYBR}^{\circledR}$ Green Real-time PCR Master Mix (Toyobo; Tokyo, Japan).

\section{Western blotting}

Chondrocytes were plated on BSA, FN, or VN and maintained in $\alpha \mathrm{MEM}$ containing $10 \% \mathrm{FBS}$ for the indicated times. In some experiments, rCCN2 $(50 \mathrm{ng} / \mathrm{ml})$ and/or cycloheximide $(20 \mu \mathrm{g} / \mathrm{ml}$; Sigma $)$ was added to the culture medium. Proteins separated by sodium dodecyl sulfate polyacrylamide gel electrophoresis (SDS-PAGE) were transferred to an Immobilon-P membrane (Millipore) using a tank transfer apparatus (BioRad, Hercules, CA). Cell lysates were prepared and western blot analysis was carried out essentially as described (Kubota et al. 2000). 
Evaluation of DNA synthesis and proteoglycan production

Mouse chondrocytes were inoculated at a density of $5 \times 10^{4}$ / well into 24-well multiplates, and cultured in $\alpha M E M$ containing $10 \%$ FBS for up to 2 days. For determination of cell proliferation, $\left[{ }^{3} \mathrm{H}\right]$ thymidine incorporation assays were performed on day 0 ( $2 \mathrm{~h}$ after inoculation), 1 , and 2 . $\left[{ }^{3} \mathrm{H}\right]$ thymidine $(37 \mathrm{MBq} / \mathrm{ml}$, PerkinElmer) was added to the cultures at a final concentration of $370 \mathrm{kBq} / \mathrm{ml}$, and incubation was continued for $4 \mathrm{~h}$. After labeling, cells were harvested and incorporation of radioactivity was determined using liquid scintillation counting. For determination of proteoglycan production, chondrocytes were cultured on chamber slides and stained for alcian blue or toluidine blue as described previously (Atsumi et al. 1990). To quantify the intensity of the staining, the dye was extracted with $1 \mathrm{ml}$ lysis buffer $(0.15 \mathrm{M} \mathrm{NaCl}, 50 \mathrm{mM}$ Tris- $\mathrm{HCl}$ ( $\mathrm{pH} 7.5)$, $3 \mathrm{mM} \mathrm{MgCl} 2,1 \mathrm{mM} \mathrm{CaCl}_{2}, 1 \%$ Triton X-100) overnight at room temperature. The optical density of extracted dye was measured at $600 \mathrm{~nm}$.

\section{Immunoprecipitation analysis}

Immunoprecipitation analysis was performed by a modification of a method described previously (Nishida et al. 2004). Briefly, cell layers were solubilized in lysis buffer and a mixture of protease inhibitors. Lysates were immunoprecipitated with antibody or heparin sepharose overnight at $4{ }^{\circ} \mathrm{C}$. Antibody complexes samples were collected by incubation with protein G-sepharose (Roche, Mannheim, Germany). Pellets were washed three times with ice-cold PBS, and precipitated proteins were solubilized in reducing SDS sample buffer. Samples were electrophoresed on SDSpolyacrylamide gels and subjected to Western blot analysis.

\section{Indirect immunofluorescence analysis}

Cells were inoculated on chamber slides (Nunc Inc., Naperville, IL) coated with FN. After $4 \mathrm{~h}$, cultures were washed with PBS, fixed with $3.5 \%$ formaldehyde for $30 \mathrm{~min}$ at room temperature, and permeabilized with $0.1 \%$ NP-40 in PBS. Indirect immunofluorescence analysis was performed as described previously (Aszodi et al. 2003). Images were obtained using either a confocal laser scanning microscope (Bio-Rad) or a light microscope (Zeiss).

\section{Immunohistochemistry}

Mouse femurs were dissected and fixed in $10 \%$ formalin overnight at $4^{\circ} \mathrm{C}$ before being embedded in paraffin. Five micrometer longitudinal sections were mounted on glass slides, deparaffinized and treated with hyaluronidase
$(25 \mathrm{mg} / \mathrm{ml})$ for $30 \mathrm{~min}$ at room temperature. Immunohistochemistry was performed with a Histofine kit (Nichirei; Tokyo, Japan). Color was developed with diaminobenzine, and sections were counterstained with methyl green. Control specimens incubated with diluted non-immune antibody showed no detectable signals.

\section{Statistical analysis}

Unless otherwise specified, all experiments were repeated at least twice, and similar results were obtained. Statistical analysis was performed by Student's $t$ test. Densitometry was performed using NIH ImageJ (Version $1.38 \mathrm{~m}$ ).

\section{Results}

Characterization of chondrocytes derived from $\mathrm{CCN} 2$ mutant mice

Chondrocytes were isolated from rib cages of E18.5 wild type (WT), $C \mathrm{Cn} 2^{+/-}$, and $C \mathrm{Cn} 2^{-/-}$mice. Cells isolated from mutant and WT mice displayed a typical chondrocyte morphology, and no differences were observed in $\mathrm{Ccn}^{-1-}$ chondrocytes compared to WT or heterozygous cells (Fig. 1a). It has been reported that recombinant CCN2 protein promotes chondrocyte proliferation and differentiation (Nakanishi et al. 2000). Therefore, we investigated whether proliferation and/or differentiation were impaired in $\mathrm{Ccn} 2^{-/-}$chondrocytes. A significant decrease in $\left[{ }^{3} \mathrm{H}\right]$ thymidine incorporation was observed in $\mathrm{Ccn}^{-/-}$chondrocyte cultures compared to WT cells (Fig. 1b). These data demonstrate that $\mathrm{CCN} 2$ is required for normal rates of chondrocyte proliferation. The effect of loss of Ccn2 on differentiation was examined by staining with toluidine blue and alcian blue to visualize cartilage matrix proteoglycans. As shown in Fig. 1c, staining with both dyes was decreased in $C \mathrm{Cn} 2^{-/}$chondrocytes; absorbance at $600 \mathrm{~nm}$ of extracted alcian blue shows that $C \mathrm{Cn} 2^{-/-}$chondrocytes exhibit an approximately $50 \%$ decrease in proteoglycan content compared to WT cells. Therefore, ECM production is significantly impaired in $\mathrm{Ccn}^{-/-}$chondrocytes.

To further investigate defects in ECM production in $\mathrm{Ccn} 2^{-/}$chondrocytes, we examined the levels of expression of specific markers. Ccn2 $2^{--}$mRNA (Fig. 2a) and protein (Fig. 2b) were undetectable in $\mathrm{Ccn}^{-/-}$chondrocytes, confirming that the previously described targeted Ccn2 mutation encodes a null allele (Ivkovic et al. 2003). Expression of both type II collagen and aggrecan mRNA and protein were decreased in $\mathrm{Ccn} 2^{-/-}$chondrocytes, compared with WT cells (Fig. 2a,b; Fig. S1a, Supplementary data). Densitometric analysis confirmed that type II collagen and aggrecan protein levels were substantially 
a
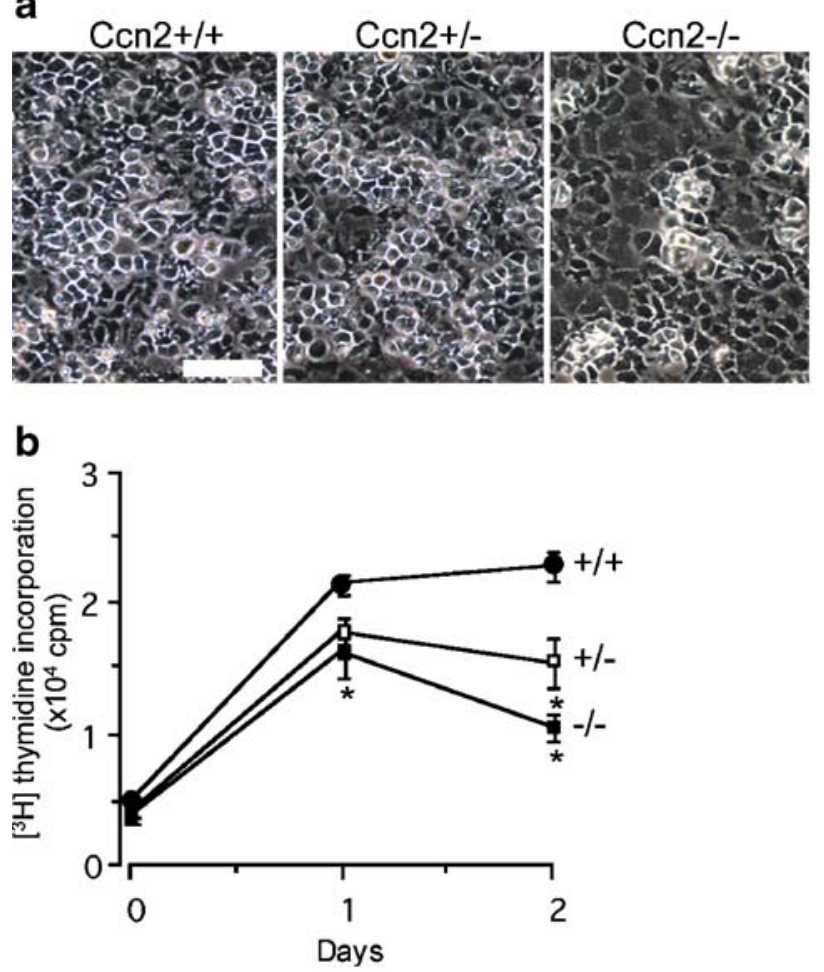

C
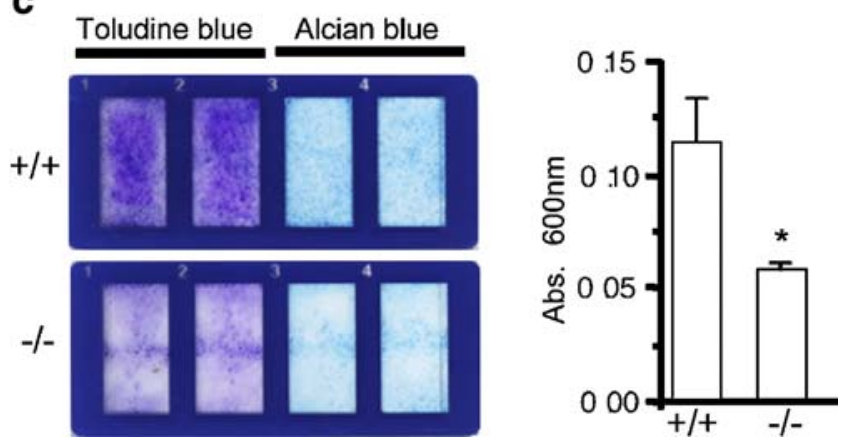

Fig. 1 Morphology and expression of cartilage markers in $\mathrm{Ccn} 2^{-/-}$ chondrocytes. a Photomicrographs of mouse chondrocytes. Chondrocytes were grown after one passage until confluent. Bar $200 \mu \mathrm{m}$. b $\mathrm{Ccn} 2^{+/+}$(filled circle), Ccn2 $2^{+/}$(open square), and $\mathrm{Ccn}^{-/-}$(filled square) chondrocytes were inoculated at a density of $5 \times 10^{4} /$ well in 24-well plates, and cultured in $\alpha$ MEM containing $10 \%$ FBS. $\left[{ }^{3} \mathrm{H}\right]$ thymidine incorporation assays were performed on days $0(2 \mathrm{~h}$ after plating), 1, and 2. Each point shows the mean and S.D. for four wells. Asterisks indicate significant differences between WT and $\mathrm{Ccn} 2^{-/-}$ cells at the significance level of $p<0.01$. c WT and $C c n 2^{-/}$ chondrocytes were cultured until confluent. Duplicate cultures of the cells were fixed in $3.5 \%$ formaldehyde, and stained with $0.05 \%$ toluidine blue or $1 \%$ alcian blue. For quantification of alcian blue staining (right panel), stained chondrocytes were dissolved in lysis buffer, and the absorbance was measured at $600 \mathrm{~nm}$. The asterisk indicates a significant difference between WT and $\mathrm{Ccn}^{-/-}$chondro-

lower in $\mathrm{Ccn} 2^{-/-}$chondrocytes (Fig. 2c). Impaired type II collagen production in $\mathrm{Ccn} 2^{-/}$cartilage has not been previously reported. Therefore, to confirm decreased expression of type II collagen, we performed immunofluorescence on WT and $\mathrm{Ccn}^{-/-}$chondrocytes. Figure 2d
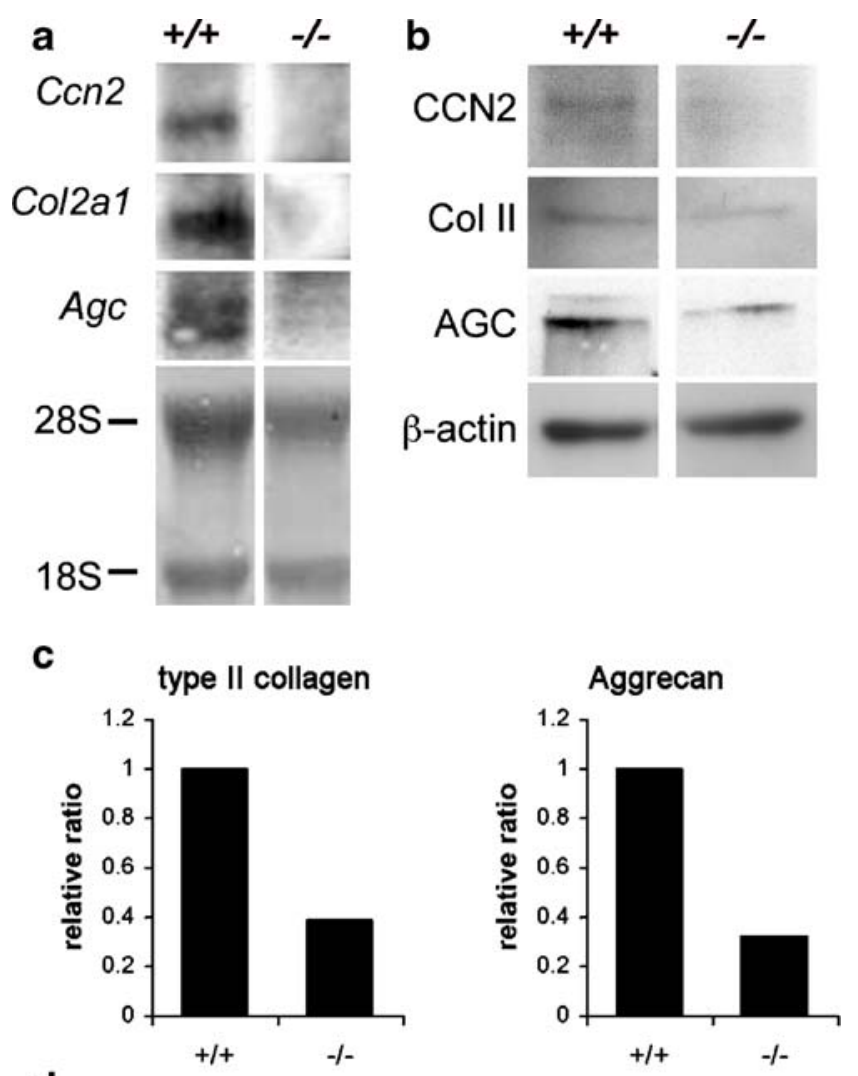

d

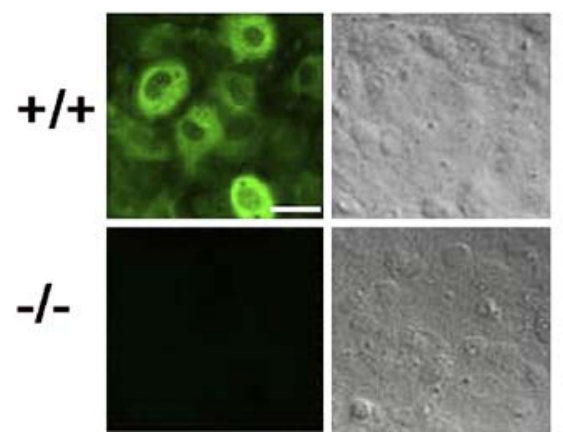

Fig. 2 Effect of $\mathrm{CCN} 2$ on chondrocyte proliferation and differentiation. Expression of Ccn2, Col2A1, and aggrecan in chondrocytes. a RNA was isolated from confluent cultures of chondrocytes and analyzed by Northern blot. The bottom panel shows methylene blue staining for ribosomal RNAs as a loading control. b Western blot analysis of CCN2, collagen type II, and aggrecan protein in whole lysates of confluent chondrocytes. The bottom panel shows $\beta$-actin as a loading control. c Densitometric analysis of protein levels of type II collagen (left panel) and aggrecan (right panel). WT levels are set at 1.0 , and the relative ratio of expression in $\mathrm{Ccn}^{-/-}$chondrocytes is indicated. Data shown are from a representative experiment. d Immunofluorescence analysis of type II collagen expression. Confocal laser scanning immunofluorescent and corresponding phase contrast images are shown for WT and $C \mathrm{cn} 2^{-1}$ chondrocytes. The bar represents $30 \mu \mathrm{m}$. The Northern, Western, and immunofluorescence analyses were repeated three times with similar results. Representative experiments are shown

shows that few $\mathrm{Ccn} 2^{-/}$chondrocytes express normal levels of type II collagen. These data are consistent with previous studies showing that exogenous $\mathrm{CCN} 2$ enhances 


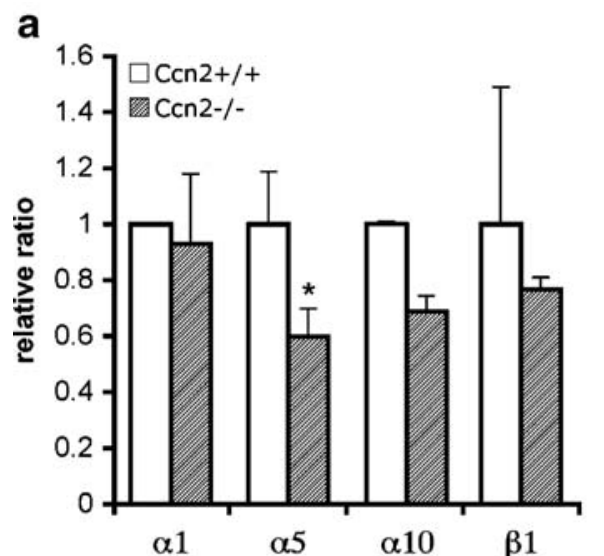

b

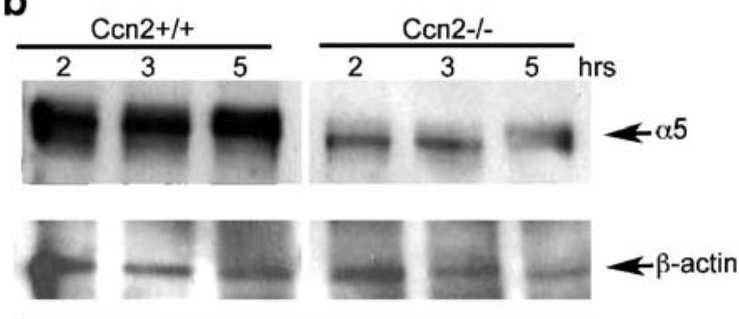

FN

e

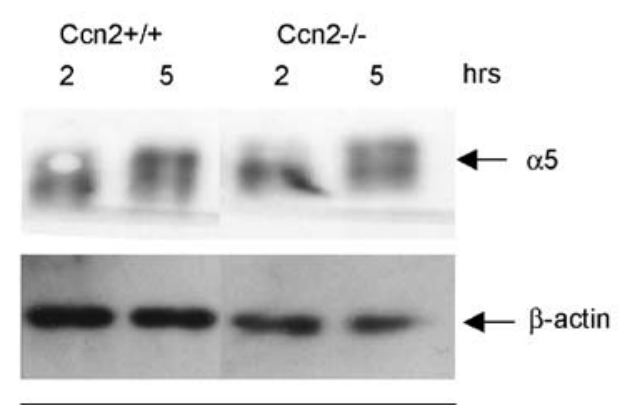

$\mathrm{VN}$

Fig. 3 Downregulation of $\alpha 5$ integrin expression and reduced adhesion of $C c n 2^{-/}$chondrocytes. a Expression of integrins $\alpha 1, \alpha 5$, $\alpha 10$, and $\beta 1$ in WT and $C \mathrm{cn} 2^{-/-}$chondrocytes. WT and $C \mathrm{cn} 2^{-/-}$ chondrocytes were cultured until confluent. Total RNA was collected and quantitative real-time RT-PCR analysis was performed. Data presented are mean and S.D. relative to WT (relative expression=1.0), of two separate reactions using mRNA from two different cultures. The asterisk indicates significance at $p<0.05$. b Western blot analysis of integrin $\alpha 5$ protein in lysates of WT and $\mathrm{Ccn}^{-/-}$chondrocytes spread on $\mathrm{FN}$ for the indicated times. Levels of integrin $\alpha 5$ are decreased in $\mathrm{Ccn} 2^{-/-}$chondrocytes beginning at the earliest stage monitored. $\mathbf{c}$ Effect of rCCN2 on the expression of integrin $\alpha 5$ in WT and $\mathrm{Ccn} 2^{-/-}$chondrocytes. WT and $\mathrm{Ccn} 2^{-/-}$cells were cultured until confluent. Thereafter, the medium was replaced with a serum-free medium containing rCCN2 at $50 \mathrm{ng} / \mathrm{ml}$, and total RNA was collected $6 \mathrm{~h}$ later. Top panel: Northern blot analysis was performed using a

ECM production in chondrocytes in vitro (Nakanishi et al. 2000). Consistent with the persistence of some type II collagen in protein lysates prepared from $\mathrm{Ccn} 2^{-/-}$chon-
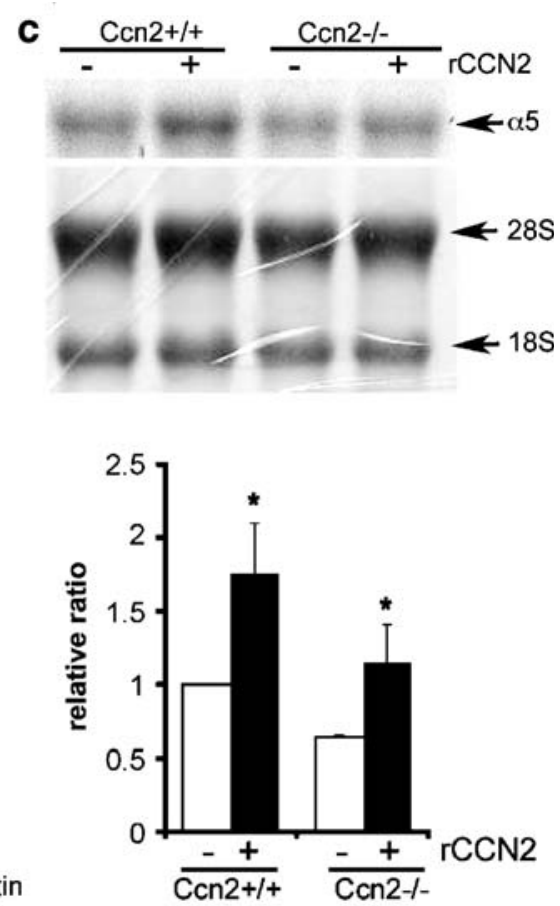

d

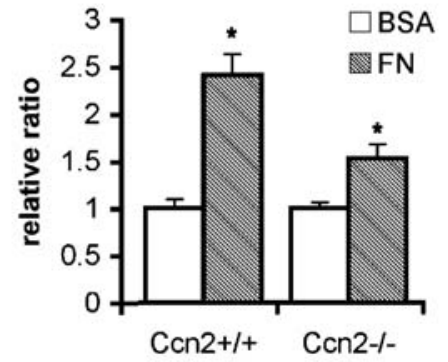

probe specific for integrin $\alpha 5$, and methylene blue staining for the ribosomal subunits. Bottom panel: The amount of integrin $\alpha 5 \mathrm{mRNA}$ was determined densitometrically and normalized to $18 \mathrm{~S}$-ribosomal RNA. Data presented are mean and S.D. relative to WT using mRNA from two different experiments. The asterisk indicates significance at $p<0.05$. d Cell attachment assay. WT and $C c n 2^{-/}$chondrocytes were inoculated at a density of $5 \times 10^{4} /$ well in 96 -well plates coated with FN or BSA (each $5 \mu \mathrm{g} /$ well) overnight. The ordinate shows the relative ratio of adhesion normalized to BSA $(=1)$. Each column represents the mean and S.D. of 10 wells. The asterisks indicate a significant difference $(p<0.05)$ between WT and $C c n 2^{-/}$chondrocytes. e Effect of $\mathrm{VN}$ on integrin $\alpha 5$ expression. WT and $\mathrm{Ccn} 2^{-/-}$chondrocytes were plated at a density of $2 \times 10^{5} /$ well in 6 -well plates coated with $\mathrm{VN}$. Levels of integrin $\alpha 5$ are decreased in $\mathrm{Ccn}^{-/-}$cells planted on $\mathrm{FN}$ (Fig. 3b), but are indistinguishable from WT when plated on VN

drocytes (Fig. 2b), type II collagen can occasionally be detected in $\mathrm{Ccn}^{-/}$cells by immunohistochemistry (Fig. S1b, Supplementary data). In contrast to the reduced 

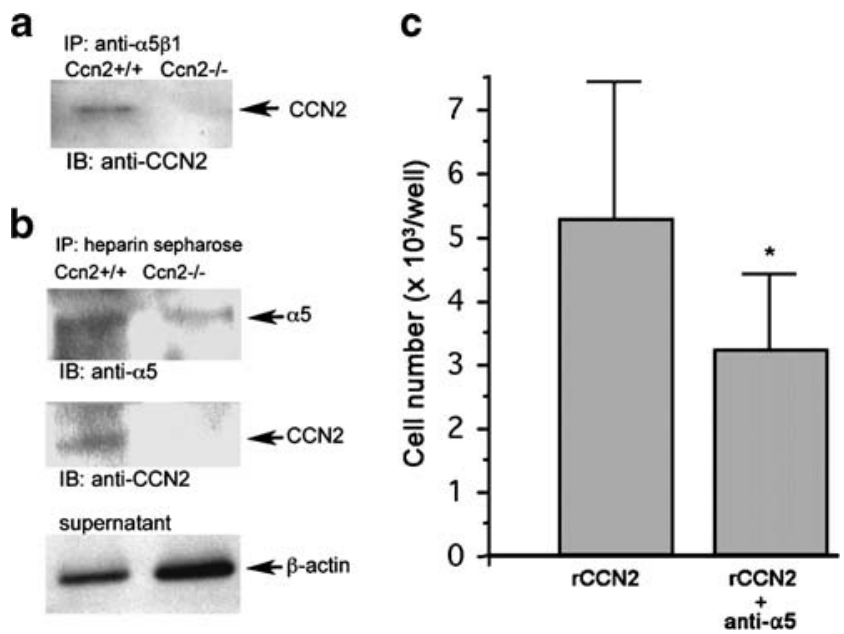

Fig. $4 \mathrm{CCN} 2$ is a ligand for integrin $\alpha 5$ in primary chondrocytes. a Complex formation between CCN2 and integrin $\alpha 5$. WT and $C \mathrm{cn} 2^{-1-}$ chondrocytes were cultured until confluent. Lysates of WT and $C \mathrm{cn} 2^{-1}$ chondrocytes were incubated with antibody against integrin $\alpha 5$, and proteins were detected by western blot with an anti-CCN2 antibody. b Lysates of WT and $\mathrm{Ccn} 2^{--}$chondrocytes were precipitated with heparin sepharose and integrin $\alpha 5$ and CCN2 were detected by Western blot. c Adhesion to rCCN2 is impaired by anti-integrin $\alpha 5$ function-blocking antibodies. Chondrocytes were plated on rCCN2-coated plates treated with or without blocking antibody. The asterisk indicates a significant difference $(p<0.05)$ between adhesion on cells in the presence or absence of the blocking antibody

expression seen in isolated $\mathrm{Ccn} 2^{-/-}$chondrocytes, type II collagen levels in intact $\mathrm{Ccn}^{-/-}$growth plates are indistinguishable from those in WT growth plates (Ivkovic et al. 2003). Compensatory mechanisms, possibly involving other CCN family members, are most likely responsible for the ability of $\mathrm{CCn}^{-/}$chondrocytes in intact growth plates and in some isolated cells to produce type II collagen. Taken together, the results demonstrate that $C c n 2$ is required in chondrocytes for normal expression of multiple cartilage-specific ECM components.

Expression and function of integrin $\alpha 5$ in $C c n 2^{-/-}$ mutant chondrocytes

It is well known that interactions of integrins with ECM components are required for cartilage proliferation and differentiation (Loeser 2002). It has also been shown that CCN2 binds several types of integrins in fibroblasts and endothelial cells (Lau and Lam 1999; Brigstock 2003; Babic et al. 1999; Leu et al. 2003; Chen et al. 2004; Hoshijima et al. 2006; Tong and Brigstock 2006; Gao and Brigstock 2005, 2006). Therefore, we examined levels of expression of various integrin subunits in chondrocytes by quantitative real-time PCR analysis. We focused on integrins $\alpha 1, \alpha 5, \alpha 10$ and $\beta 1$ because loss-of-function approaches have revealed roles for these subunits in intact a
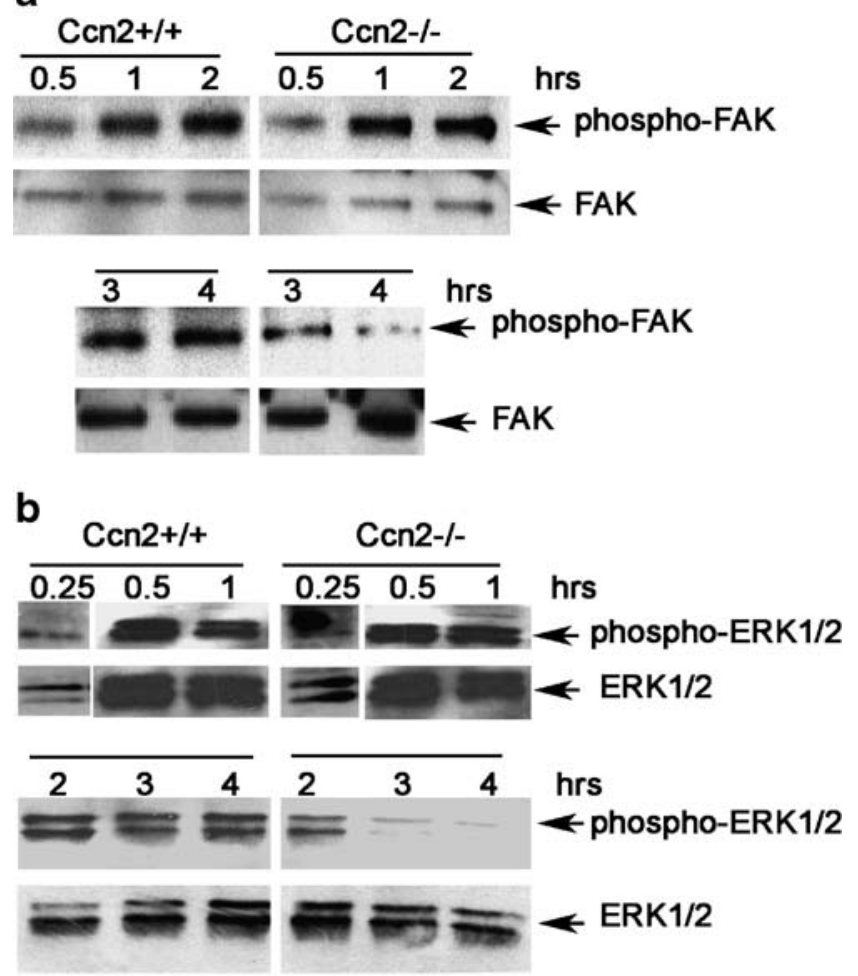

C

Ccn2- -

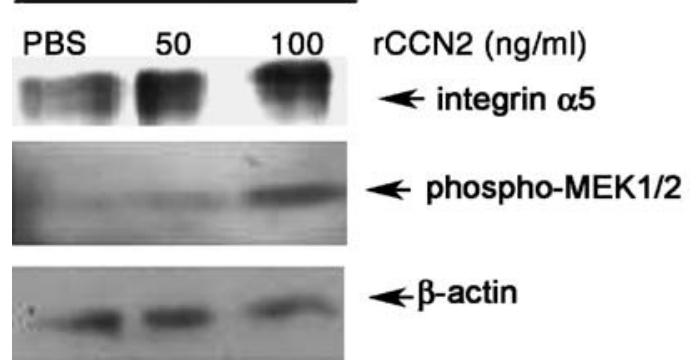

Fig. 5 Western blot analysis of phospho-FAK and phospho-ERK1/2 in WT and Ccn 2 mutant cells. a CCN2 is required for maintenance of phospho-FAK activity on FN. WT or $\mathrm{Ccn}^{-/-}$chondrocytes were inoculated on $\mathrm{FN}(5 \mu \mathrm{g} / \mathrm{well})$ at $37^{\circ} \mathrm{C}$ overnight. Cell lysates were collected $0.5,1,2,3$, or $4 \mathrm{~h}$ after inoculation, and immunoprecipitated with anti-FAK antibody at $4^{\circ} \mathrm{C}$ overnight. The precipitates were subjected to SDS-PAGE and Western blot was performed with antiphospho-FAK and anti-FAK antibodies. b CCN2 is required for maintenance of pERK1/2 levels of FN. WT or $C c n 2^{-/-}$cells were cultured as above for the indicated times. Immunoprecipitation was performed with anti-ERK1/2 antibody, followed by detection with anti-phospho-ERK1/2 and anti-ERK1/2 antibodies. c Ability of rCCN2 to rescue pMEK1/2 activity in $\mathrm{Ccn}^{-1-}$ chondrocytes plated on FN. Cells were plated on FN as described above, and maintained in the absence or presence of $\mathrm{rCCN} 2$ at the indicated concentrations for $4 \mathrm{~h}$. Integrin $\alpha 5$ and pMEK1/2 were detected by Western blot analysis

cartilage in vivo (Aszodi et al. 2003; Garciadiego-Cázares et al. 2004; Zemmyo et al. 2003; Ekholm et al. 2002; Bengtsson et al. 2005). Moreover, exogenous CCN2 
upregulates integrin $\alpha 5$ expression in normal rat kidney (NRK) fibroblasts (Frazier et al. 1996), suggesting that $\mathrm{Ccn} 2^{-/-}$chondrocytes might exhibit reduced expression of this integrin subunit. Indeed, expression of integrin $\alpha 5$ was decreased in $\mathrm{Ccn} 2^{-/-}$chondrocytes compared to WT cells (Fig. 3a). Expression of integrin $\alpha 10$ showed a trend towards decreased expression in $\mathrm{Ccn}^{-/}$cells, but the difference did not reach statistical significance. Expression of the other integrins was not obviously different (Fig. 3a). To confirm that integrin $\alpha 5$ protein was decreased, we analyzed protein levels in $C c n 2^{-/-}$chondrocytes plated on FN. Figure $3 b$ shows that integrin $\alpha 5$ protein is expressed at significantly lower levels in $\mathrm{Ccn} 2^{-/}$chondrocytes compared to WT cells at all time points monitored, reflecting the decrease observed in mRNA. These results raised the possibility that $\mathrm{CCN} 2$ could be directly involved in determining the expression level of integrin $\alpha 5$ in chondrocytes. To investigate this possibility further, we examined the effects of culturing WT and $\mathrm{Ccn} 2^{-1-}$ chondrocytes in the presence of recombinant CCN2 protein (rCCN2). Both WT and $\mathrm{Ccn} 2^{-/-}$chondrocytes exhibited increased expression of integrin $\alpha 5$ in the presence of rCCN2 (Fig. 3c), suggesting that CCN2 indeed has a positive role in regulating levels of integrin $\alpha 5$ expression. To determine whether the ability of rCCN2 to restore expression of integrin $\alpha 5$ was a direct or indirect effect, we investigated whether rCCN2 could increase integrin $\alpha 5$ mRNA levels in WT chondrocytes in the presence of cycloheximide. Under these conditions, no increased integrin $\alpha 5$ expression was observed (data not shown), indicating that new protein synthesis is required for rCCN2 to upregulate integrin $\alpha 5$ levels in chondrocytes.

Integrin $\alpha 5 \beta 1$ is the major receptor for $\mathrm{FN}$, and a major receptor for COMP (cartilage oligomeric matrix protein) in chondrocytes (Chen et al. 2005). Therefore, we investigated whether $\mathrm{Ccn} 2^{-/}$chondrocytes exhibit impaired ability to bind to FN. Figure 3d shows that, consistent with decreased integrin $\alpha 5$ expression, adhesion of $\mathrm{Ccn}^{-/-}$chondrocytes to $\mathrm{FN}$ was reduced. The results described above suggest that $\mathrm{Ccn} 2^{-/-}$cells are defective in adhesion to $\mathrm{FN}$, at least in part because of decreased $\alpha 5 \beta 1$ expression. It has been shown previously that FN-mediated adhesive signaling maintains integrin $\alpha 5$ expression (Huang et al. 1994; Larouche et al. 2000), suggesting that the impaired adhesion to $\mathrm{FN}$ seen in $\mathrm{Ccn} 2^{-/}$cells can be both a cause, and a consequence of, reduced integrin $\alpha 5$ expression, and that $\mathrm{CCN} 2$ plays a direct role in the positive feedback loop by which FN binding to $\alpha 5 \beta 1$ integrin upregulates integrin $\alpha 5$ expression. If so, integrin $\alpha 5$ levels should be similar in WT and $C c n 2^{-/}$cells plated on VN, which does not engage integrin $\alpha 5 \beta 1$. As previously described, $C c n 2^{-/}$ chondrocytes exhibit impaired expression of integrin $\alpha 5$ on FN (Fig. 3b); however, $\alpha 5$ levels were indistinguishable between WT and $C c n 2^{-/}$cells when they were plated on VN (Fig. 3e). These results imply that the decreased adhesion exhibited by $\mathrm{Ccn} 2^{-/-}$chondrocytes on $\mathrm{FN}$ and under normal conditions, where they produce their own matrix, is mediated by $\alpha 5 \beta 1$ integrins, and that this decreased adhesion is responsible for the decreased integrin $\alpha 5$ expression.

CCN2 physically interacts with $\alpha 5 \beta 1$ in fibroblasts (Chen et al. 2004), hepatic and pancreatic stellate cells (Gao and Brigstock 2005, 2006) and in a chondrosarcomaderived cell line (Hoshijima et al. 2006). Therefore, we tested whether CCN2 physically interacts with $\alpha 5 \beta 1$ integrin in primary chondrocytes. Integrin $\alpha 5$ was precipitated from WT and $\mathrm{Ccn} 2^{-/-}$chondrocyte lysates, followed by Western blotting with antibodies against CCN2. Figure $4 \mathrm{a}$ shows that CCN2 can be detected in integrin $\alpha 5$ precipitates from WT chondrocytes, but not from $\mathrm{Ccn} 2^{-/}$cells, demonstrating that CCN2 binds integrin $\alpha 5$ in primary chondrocytes. In the absence of an antibody that precipitates CCN2, we used heparin sepharose to precipitate lysates, because CCN2 binds heparin strongly. As shown in Fig. 4b, binding of integrin $\alpha 5$ to heparin was observed in cell lysates from both WT and $C c n 2^{-/-}$ chondrocytes; however, the intensity of the band was decreased in lysates from mutant cells, consistent with the decreased expression of $\alpha 5$ integrin. When these immunoprecipitates were immunoblotted to detect $\mathrm{CCN} 2$, this protein was clearly present in WT chondrocytes, but absent in $\mathrm{Ccn}^{-/}$chondrocytes. These data demonstrate that

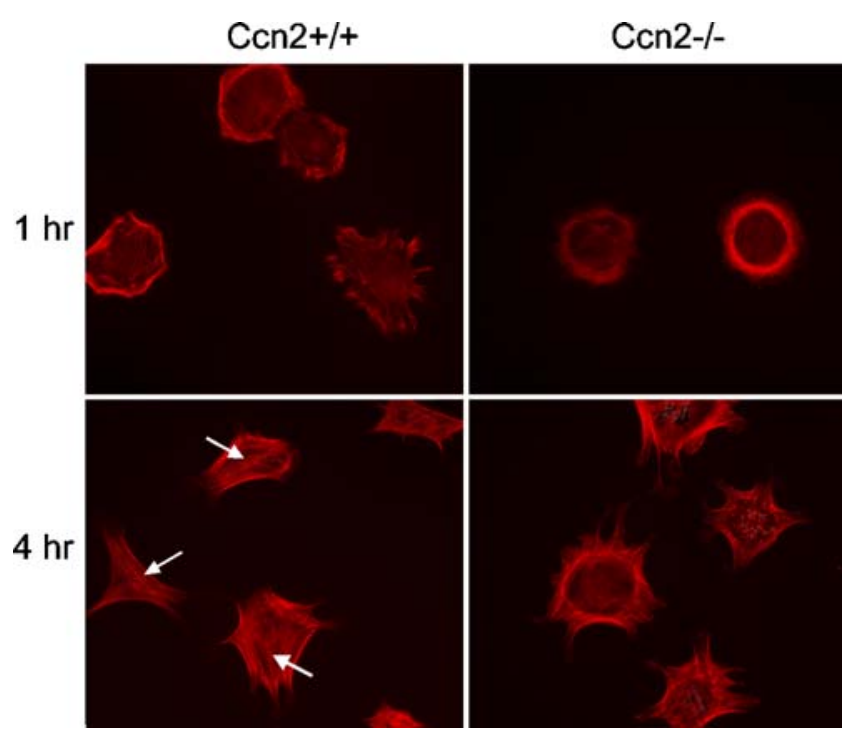

Fig. 6 Immunofluorescence analysis of the actin cytoskeleton in WT or $\mathrm{Ccn2}^{-/-}$chondrocytes on FN. WT and $\mathrm{Ccn} 2^{-/-}$chondrocytes were spread on FN coated with slides for $1 \mathrm{~h}$ or $4 \mathrm{~h}$. The cultures were fixed with $3.5 \%$ formaldehyde, permeabilized with $0.1 \%$ NP-40 in PBS, and stained with phalloidin conjugated to alexa fluor-555 to visualize actin filaments. Arrows indicate stress fibers 
CCN2 is an endogenous ligand for integrin $\alpha 5$ in chondrocytes.

In order to test the potential significance of integrin $\alpha 5$ as a receptor for $\mathrm{CCN} 2$ in chondrocytes, we examined the effect of blocking antibodies to integrin $\alpha 5$ on the ability of these cells to adhere to exogenous CCN2. As shown in Fig. 4c, adhesion of primary chondrocytes to rCCN2 is impaired by the integrin $\alpha 5$ blocking antibody. This result indicates that integrin $\alpha 5$ is a receptor for CCN2 in primary chondrocytes. Taken together, the data thus suggest that $\mathrm{CCN} 2$ regulates chondrocyte function both as a ligand for integrin $\alpha 5$, and as a regulator of $\alpha 5$ expression.
CCN2 maintains phosphorylation of FAK and ERK1/2 in chondrocytes

Because expression of integrin $\alpha 5$ and adhesion to $\mathrm{FN}$ were decreased in $\mathrm{Ccn} 2^{-/-}$chondrocytes, and CCN2 is known to activate focal adhesion kinase (FAK) (Chen et al. 2001), we tested whether adhesive signaling was also impaired in Ccn 2 deficient cells. Ligation of $\beta 1$ integrins results in phosphorylation of FAK as it is recruited to focal adhesions, leading to activation of the downstream extracellular signal-regulated kinase (ERK)1/2 pathway (Schlaepfer et al. 1999). WT and $\mathrm{Ccn}^{-/-}$chondrocytes
Fig. 7 Immunofluorescence analysis of phospho-FAK and phospho-ERK1/2 in WT or $\mathrm{Ccn} 2^{-/-}$chondrocytes. WT $(\mathbf{a}-\mathbf{c}, \mathbf{g}-\mathbf{i})$ and $C \mathrm{Cn} 2^{-/-}(\mathbf{d}-\mathbf{f}, \mathbf{j}-\mathbf{l})$ chondrocytes were spread on FN coated slides for $1 \mathrm{~h}(\mathbf{a}-\mathbf{f})$ or $4 \mathrm{~h}(\mathrm{~g}-\mathbf{l})$. Localization of phospho-FAK (a, d, g, j) and phospho-ERK1/2 (b, e, h, k) was visualized by indirect immunofluorescence. Microphotographs of a single field stained with anti-phospho-FAK (green) and phospho-ERK1/2 (red) antibodies and with DAPI (c, f, i, l).

The arrows indicate focal adhesions (a and g). Bar represents $50 \mu \mathrm{m}$

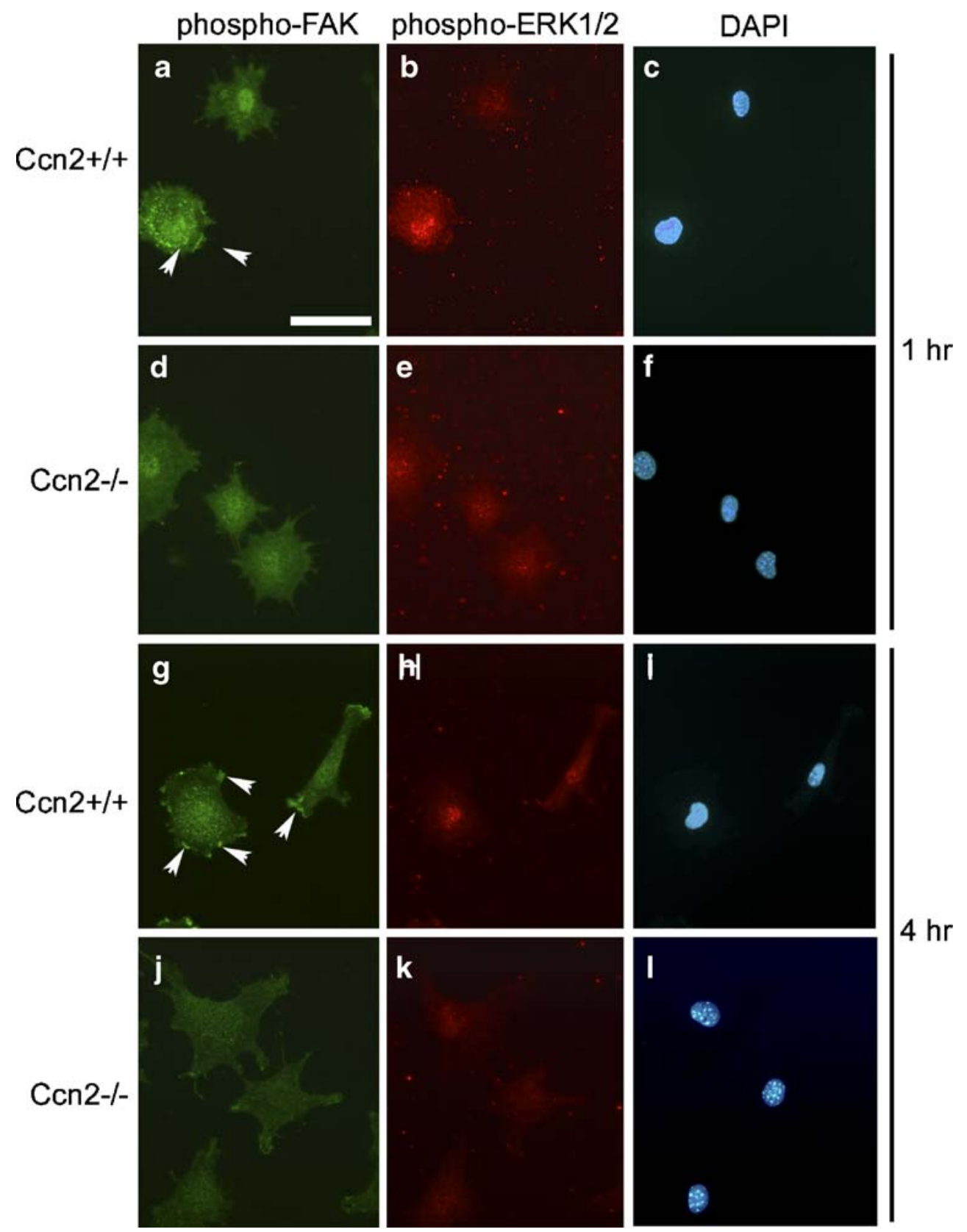


were allowed to adhere to $\mathrm{FN}$ for various times before immunoprecipitation analysis with antibodies specific for total FAK or the phosphorylated (activated) form. At early time points (up to $2 \mathrm{~h}$ ) levels of FAK phosphorylation were similar in WT and $\mathrm{Ccn} 2^{-/}$chondrocytes. However, at later times the degree of phosphorylation decreased considerably in the $\mathrm{CCn}^{-/}$chondrocytes (Fig. 5a). Similar results were obtained when levels of ERK1/2 phosphorylation were examined (Fig. 5b). To determine whether the decreased expression of integrin $\alpha 5$ may contribute to the reduced adhesive signaling in $\mathrm{Ccn} 2^{-/}$chondrocytes, we tested whether rCCN2 could restore both integrin $\alpha 5$ and phospho-MEK1/2 levels. As shown in Fig. 5c, rCCN2 at $50 \mathrm{ng} / \mathrm{ml}$ and $100 \mathrm{ng} / \mathrm{ml}$ increased integrin $\alpha 5$ levels on chondrocytes plated on FN (Fig. 5c). Moreover, increased phospho-MEK $1 / 2$ levels were observed in the presence of $100 \mathrm{ng} / \mathrm{ml} \mathrm{rCCN} 2$ (Fig. 5c). The fact that integrin $\alpha 5$ levels are increased by $50 \mathrm{ng} / \mathrm{ml} \mathrm{rCCN2}$, but elevation of phospho-MEK $1 / 2$ levels requires a higher concentration $(100 \mathrm{ng} / \mathrm{ml})$ of $\mathrm{rCCN} 2$ raises the likelihood that the ability of $\mathrm{CCN} 2$ to upregulate integrin $\alpha 5$ expression is required, but that rCCN2 also mediates additional activities to maintain adhesive signaling in chondrocytes.

Subcellular localization of actin, phosho-FAK, and phospho-ERK1/2 in $\mathrm{Ccn}^{-/-}$chondrocytes

The role of CCN2 in adhesive signaling in chondrocytes was further investigated by indirect immunofluorescence. WT and $C \mathrm{Cn} 2^{-/}$chondrocytes were seeded on FN for 1 or $4 \mathrm{~h}$ before being fixed in formaldehyde, and actin filaments visualized with phalloidin conjugated to a fluorescent marker (Fig. 6). The majority of actin is present close to the cell periphery in WT and $C \mathrm{Cn} 2^{-/}$chondrocytes seeded for $1 \mathrm{~h}$ on FN. After $4 \mathrm{~h}$ there are differences between WT and $C \mathrm{Cn} 2^{-/-}$chondrocytes; in WT chondrocytes stress fibers are evident, whereas in $\mathrm{Ccn}^{-/-}$cells the majority of the actin remains close the cell periphery, consistent with defective adhesive signaling.

To investigate this possibility further, we subjected WT and $\mathrm{CCn}^{-/-}$chondrocytes to double immunostaining with anti-phospho-FAK and anti-phospho-ERK1/2 antibodies. Phospho-FAK is a marker for focal adhesions (e.g., Almeida et al. 2000; Ruest et al. 2000; Holinstat et al. 2006; Zaidel-Bar et al. 2007). As shown in Fig. 7, immunoreactivity for phospho-FAK was detected in the nucleus in both WT and $C \mathrm{Cn} 2^{-/-}$chondrocytes after $1 \mathrm{~h}$ on $\mathrm{FN}$, and Western blot analysis revealed similar overall levels of phospho-FAK (Fig. 5a). However, staining in focal adhesions was seen only in WT cells (Fig. 7a,d; arrows). In WT cells, the presence of phospho-FAK in the nucleus and in focal adhesions persisted after $4 \mathrm{~h}$ on FN (Fig. 7g). However, phospho-FAK could not be detected in the nucleus or in focal adhesions of $\mathrm{Ccn}^{-/-}$chondrocytes after $4 \mathrm{~h}$ on FN (Fig. 7j). Indirect immunofluorescence for vinculin and phospho-tyrosine, additional markers for focal adhesions (Hamadi et al. 2005; Ballestrem et al. 2006; Robels and Gomez 2006; Sawada et al. 2006) confirmed that focal adhesion formation is defective in $\mathrm{Ccn} 2^{-/-}$ chondrocytes (Fig. 8). In the case of phospho-ERK1/2, immunoreactivity was seen in the nucleus and cytoplasm of WT chondrocytes after $1 \mathrm{~h}$ on FN (Fig. 7b), and persisted in the nucleus after $4 \mathrm{~h}$ (Fig. 7h). However, both nuclear and cytoplasmic staining of phosph-ERK1/2 was reduced in $\mathrm{CCn}^{-/}$chondrocytes after 1 and $4 \mathrm{~h}$ on FN (Fig. 7e,k).
Fig. 8 Focal adhesion formation in WT and $\mathrm{Ccn} 2^{-1-}$ chondrocytes. a, b WT and $C c n 2^{-/}$ chondrocyte, respectively, plated on $\mathrm{FN}$ for $4 \mathrm{~h}$ followed by indirect immunofluorescence analysis of vinculin expression. Focal adhesions are seen at the periphery of the WT cell but not the mutant cell. $\mathbf{c}, \mathbf{d}$ WT and $\mathrm{Ccn} 2^{-/-}$chondrocyte, respectively, stained with anti-phosphotyrosine antibody (PY-20)
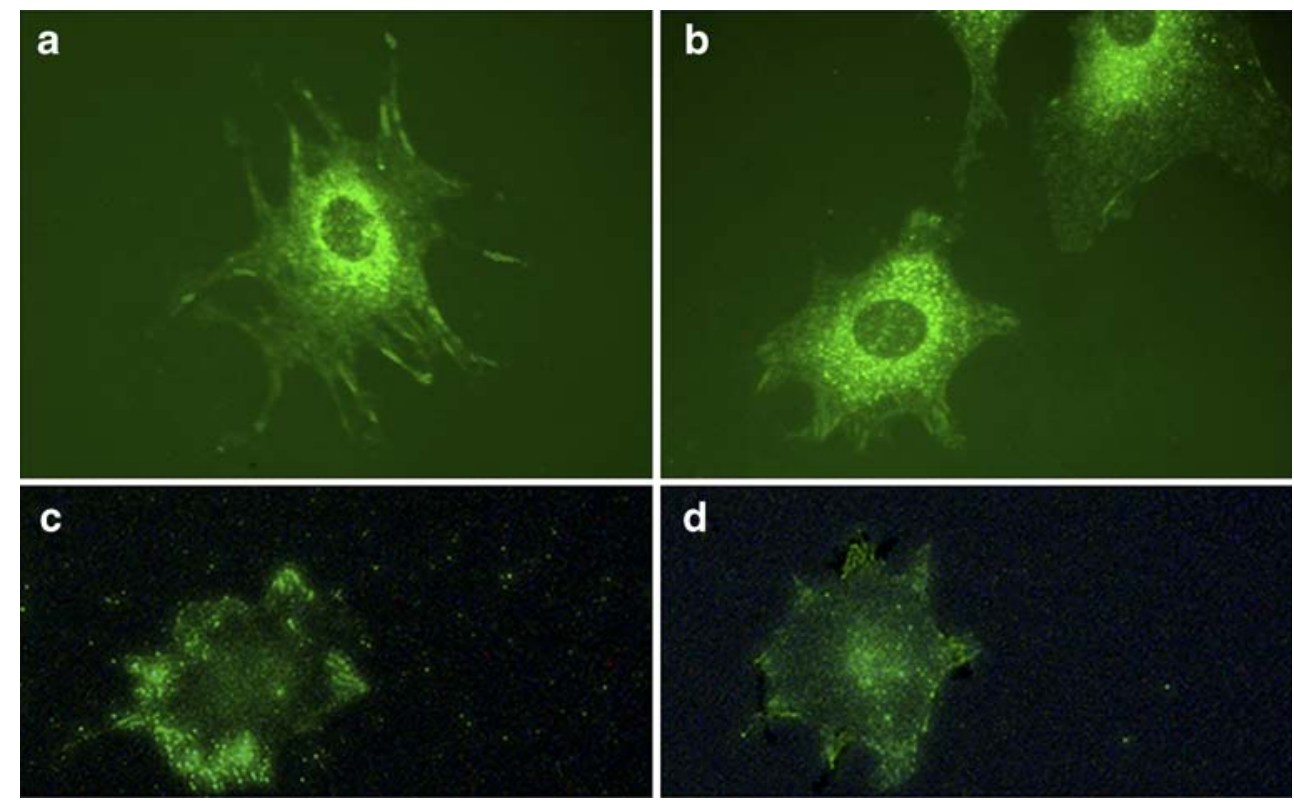
Fig. 9 Immunolocalization of $\alpha 5 \beta 1$ integrin in sections of growth plate cartilage of WT and $\mathrm{Ccn} 2^{-/-}$mice. Sections of growth plates of E18.5 femurs at identical levels in WT and $\mathrm{Ccn}^{-/-}$littermates were stained with safranin-O $(\mathbf{a}, \mathbf{b})$, and reacted with anti- $\alpha 5 \beta 1$ integrin $(\mathbf{c}, \mathbf{d})$. The primary antibodies were visualized by immunoperoxidase, and then the sections were counterstained with methyl green. $\alpha 5 \beta 1$ integrin was localized throughout the growth plate, with highest levels of expression in the hypertrophic zone (HZ) of the WT growth plate. Lower levels of expression are seen in the hypertrophic zone in the mutant growth plate. Bar represents $100 \mu \mathrm{m}$

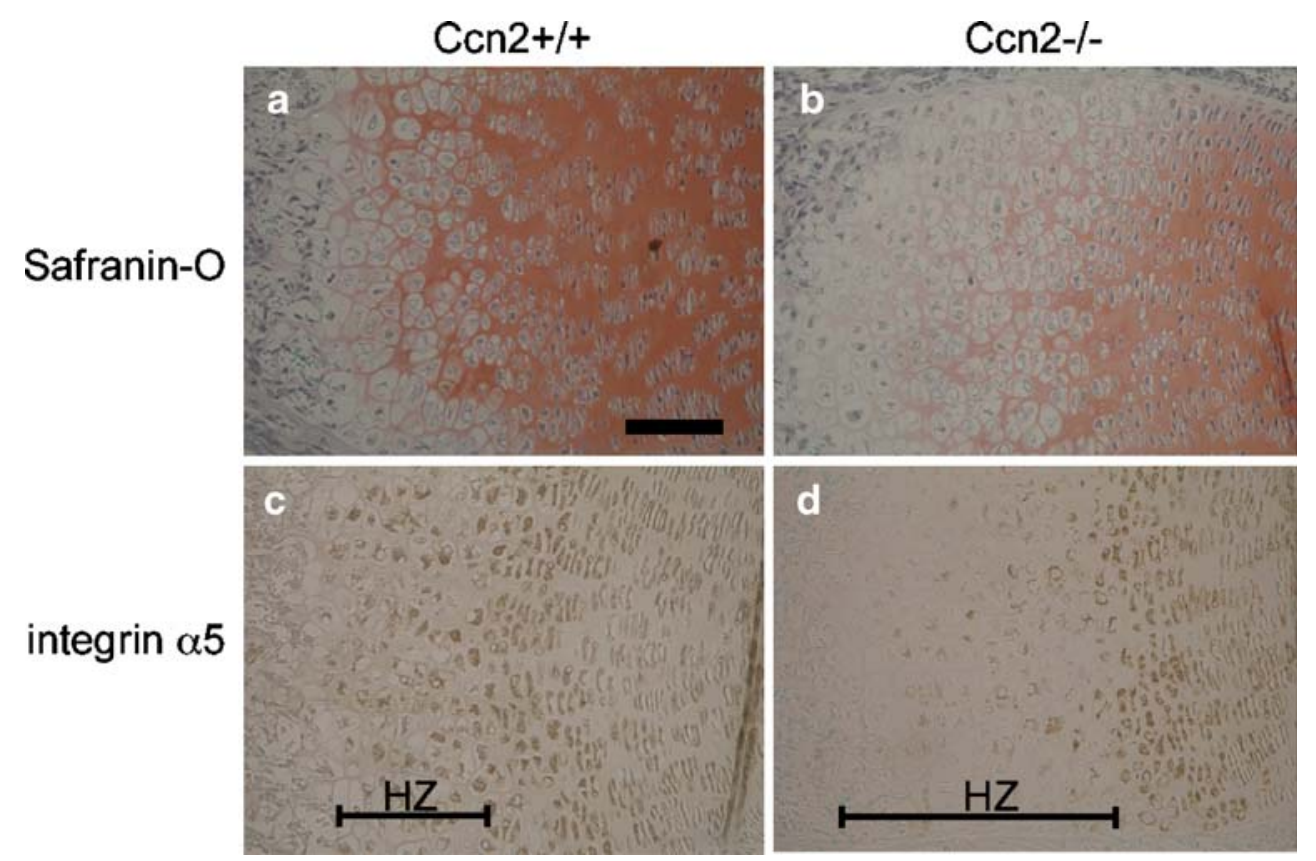

These findings are consistent with the results in Fig. 5 and indicate that cell signaling through integrin receptors for FN via phospho-FAK and phospho-ERK1/2 is maintained in WT, but not in $\mathrm{CCn}^{-/-}$chondrocytes.

Immunolocalization of integrin $\alpha 5$ in WT and $C c n 2^{-/-}$ growth plates

Our data suggest that CCN2 is essential for ECM production and both induces the expression of integrin $\alpha 5$, and binds to it. To determine whether decreased expression of ECM components and/or integrin $\alpha 5$ might contribute to the chondrodysplaisa observed in $\mathrm{Ccn}^{-/-}$ mice, we examined proteoglycan production and the localization of integrin $\alpha 5$ in endochondral bone. As shown in Fig. 9, an enlarged hypertrophic zone was seen in the growth plate in $\mathrm{Ccn} 2^{-/-}$mice compared to WT littermates (panels a and b), consistent with previous studies (Ivkovic et al. 2003). Safranin-O staining revealed reduced levels of proteoglycans in cartilage throughout $\mathrm{Ccn2}^{-/-}$growth plates (Fig. 9a and b). This finding is consistent with the results shown in Fig. 2 and with previous studies indicating that aggrecan levels are reduced in $\mathrm{Ccn}^{-/}$growth plates (Ivkovic et al. 2003). In accordance with previous studies (Loeser 2002), immunoreactivity for integrin $\alpha 5$ was detected throughout the WT growth plate, with highest levels in the prehypertrophic and hypertrophic zones (Fig. 9c). This pattern of expression corresponds closely with that of CCN2 in the growth plate; CCN2 is expressed at low levels in proliferating chondrocytes and at much higher levels in the hypertrophic zone (Ivkovic et al. 2003; Nishida et al. 2002). The pattern of integrin $\alpha 5$ expression is significantly reduced in $\mathrm{C} \mathrm{Cn} 2^{-/-}$mice, with the greatest reduction in the hypertrophic zone chondrocytes (Fig. 9 compare panels $\mathrm{c}$ and $\mathrm{d}$ ). The finding that integrin $\alpha 5$ expression is reduced in $\mathrm{Ccn}^{-/-}$growth plates, and this reduction is most evident in the hypertrophic zone, which normally expresses the highest levels of $\mathrm{CCN} 2$, strongly suggests that integrin $\alpha 5$ is a major mediator of the effects of CCN2 in vivo in chondrocytes.

\section{Discussion}

Previous studies have shown that CCN2 is an essential regulator of chondrogenesis (Ivkovic et al. 2003). Chondrocyte proliferation, ECM composition, matrix remodeling and growth plate angiogenesis are all impaired in $\mathrm{Ccn} 2^{-/}$ growth plates. The mechanisms by which loss of CCN2 leads to these defects are unknown. We have investigated potential mechanisms of action of $\mathrm{CCN} 2$ in chondrocytes in this report.

We find that chondrocytes isolated from $\mathrm{Ccn}^{-/}$mice exhibit impaired type II collagen and aggrecan expression, matrix synthesis, and proliferation, consistent with and extending our previous findings in vivo (Ivkovic et al. 2003). Moreover, we find that CCN2 is an essential regulator of integrin $\alpha 5$ expression and function in chondrocytes. We show here that $\mathrm{rCCN} 2$ induces integrin $\alpha 5$ expression, and that endogenous $\mathrm{CCN} 2$ is required for normal levels of integrin $\alpha 5$ expression in chondrocytes. 
Recently, it was reported that blocking $\alpha 5 \beta 1$ integrin function in vivo inhibits pre-hypertrophic chondrocyte differentiation (Garciadiego-Cázares et al. 2004). In this study, we show that decreased expression of integrin $\alpha 5$ in $\mathrm{Ccn} 2^{-/}$chondrocytes correlates with defective chondrocyte differentiation and ECM production in vitro and in vivo. Interestingly, the expression pattern of integrin $\alpha 5$ in the cartilage strongly resembles that previously shown for CCN2 (Nakanishi et al. 2000; Ivkovic et al. 2003; Nishida et al. 2002). This strongly suggests a potential role for $\mathrm{CCN} 2$ as an endogenous regulator of integrin $\alpha 5$ expression. However, CCN2 cannot be the only regulator of integrin $\alpha 5$ expression in cartilage because it is clearly present in $\mathrm{CCn}^{-/-}$growth plates (Fig. 9), and isolated $\mathrm{Ccn} 2^{-/}$primary chondrocytes retain low levels of integrin $\alpha 5$ expression (Fig. 3a,b). It is conceivable that the related family member CCN1 (CYR61), which is expressed in proliferative and pre-hypertrophic chondrocytes (Wong et al. 1997), can compensate at least in part for loss of Ccn2 and is responsible for the residual level of integrin $\alpha 5$ expression. We conclude that regulation of integrin $\alpha 5$ expression represents one, but not the only, mechanism underlying the requirement for $\mathrm{CCN} 2$ in chondrogenesis. That additional mechanisms of CCN2 action are responsible for the defects in adhesive signaling in Ccn2 mutant chondrocytes is further suggested by the finding that $\mathrm{rCCN} 2$ at $50 \mathrm{ng} / \mathrm{ml}$ can rescue integrin $\alpha 5$ expression, but not phospho-MEK1/2 levels (Fig. 5).

We have shown that CCN2 is present in a complex with integrin $\alpha 5$ in chondrocytes. Our data support the hypothesis that $\mathrm{CCN} 2$ is required for efficient signaling by integrin $\alpha 5$ in chondrocytes. Although initial phosphorylation of FAK and ERK1/2 appears to be normal in $\mathrm{Ccn}^{-/-}$ chondrocytes, the signal is transient compared to the persistence of these signals in WT cells. The basis for this inability of mutant chondrocytes to maintain phospho-FAK and phospho-ERK1/2 at normal levels is currently unknown, but warrants investigation in the future. Immunofluorescence studies verified defective focal adhesion formation in $\mathrm{Ccn}^{-/}$chondrocytes. In addition, there are significant phenotypic similarities in the defects observed in $\mathrm{CCn}^{-/-}$growth plates and those in mice that lack expression of integrin $\beta 1$ (Aszodi et al. 2003). Taken together, these data are consistent with the hypothesis that $\mathrm{CCN} 2$ is required for integrin-mediated signaling in chondrocytes, particularly through integrin $\alpha 5 \beta 1$. Our data show that CCN2 not only induces integrin $\alpha 5$ expression (Fig. 3c) and is required for normal expression levels in vivo (Fig. 9), but that integrin $\alpha 5$ also interacts directly with $\mathrm{CCN} 2$ in chondrocytes (Fig. 4).

It has been shown that expression of integrin $\alpha 5$ is upregulated by exogenous CCN2 in fibroblasts (Frazier et al. 1996; Weston et al. 2003). Recently, Chen et al. investigated cell adhesion to fibronectin using $C \mathrm{cn} 2^{-/-}$embryonic fibroblasts, and showed that loss of endogenous CCN2 resulted in impaired spreading on fibronectin, delayed stress fiber formation, and reduced FAK and ERK1/2 phosphorylation (Chen et al. 2004). Interestingly, in contrast to our finding that integrin $\alpha 5 \mathrm{mRNA}$ and protein levels are reduced in $\mathrm{Ccn} 2^{-/}$chondrocytes (Fig. 3a,b), no such effect on $\alpha 5$ integrin transcription was observed in $\mathrm{Ccn} 2^{-/-}$ fibroblasts (Chen et al. 2004). However, our results are consistent with other reports that $\alpha 5$ integrin signaling induces $\alpha 5$ integrin transcription (Huang et al. 1994). The observation that FAK and ERK1/2 cannot be maintained in $\mathrm{CCn}^{-/-}$chondrocytes (Figs. 5 and 7) provides strong support for the hypothesis that the chondrodysplasia observed in $\mathrm{CCn}^{-/-}$growth plates is due at least in part to defective integrin-ECM interactions.

In conclusion, $\mathrm{CCN} 2$ is an essential regulator of ECM expression and both the expression and signaling properties of integrin $\alpha 5$; moreover CCN2 mediates signaling through the activation of ERK1/2 via integrin signaling in chondrocytes. The phenotypic correspondence between $\beta 1$ integrin-deficient mice (Aszodi et al. 2003) and $\mathrm{Ccn}^{-/}$ mice (Ivkovic et al. 2003) is consistent with the possibility that a primary mode of action for CCN2 is through its ability to regulate integrin signaling.

CCN2 has been proposed to bind directly to a variety of growth factors, including Transforming growth factor (TGF)- $\beta$, Bone morphogenetic proteins (BMPs), and vascular endothelial growth factor (VEGF), all of which have profound effects on the growth plate (Serra et al. 1997; Inoki et al. 2002; Abreu et al. 2002; Zelzer et al. 2002; Yoon et al. 2005, 2006; Baffi et al. 2006). Future studies will be required to determine the physiological relevance of these activities of $\mathrm{CCN} 2$, to determine whether $\mathrm{CCN} 2$ exerts overlapping functions with other $\mathrm{CCN}$ family members in cartilage, and to detect additional functions for $\mathrm{CCN} 2$ in other aspects of disease and development.

Acknowledgments We thank members of our laboratory for suggestions and comments on this manuscript, and Maryam Hosseini for technical assistance. This work was supported by a grant from the National Institutes of Health to K. M. L (AR052686) and the Scleroderma Foundation (K.M.L).

Statement of competing interests The authors declare that they have no competing interests.

\section{References}

Abreu JG, Ketpura NI, Reversade B, De Robertis EM (2002) Connective-tissue growth factor (CTGF) modulates cell signaling by BMP and TGF- $\beta$. Nat Cell Biol 4:599-604

Almeida EA, Ilic D, Han Q, Hauck CR, Jin F, Kawakatsu H, Schlaepfer DD, Damsky CH (2000) Matrix survival signaling: 
from fibronectin via focal adhesion kinase to c-Jun NH2-terminal kinase. J Cell Biol 149:741-754

Asano M, Kubota S, Nakanishi T, Nishida T, Yamaai T, Yosimichi G, Ohyama K, Sugimoto T, Murayama Y, Takigawa M (2005) Effect of connective tissue growth factor (CCN2/CTGF) on proliferation and differentiation of mouse periodontal ligamentderived cell. Cell Commun Signal 3:11

Aszodi A, Hunziker EB, Brakebusch C, Fässler R (2003) $\beta 1$ integrins regulate chondrocyte rotation, G1 progression, and cytokinesis. Genes Dev 17:2465-2479

Atsumi T, Miwa Y, Kimata K, Ikawa Y (1990) A chondrogenic cell line derived from a differentiating culture of AT805 teratocarcinoma cells. Cell Differ Dev 30:109-116

Babic AM, Chen CC, Lau LF (1999) Fisp12/mouse connective tissue growth factor mediates endothelial cell adhesion and migration through integrin $\alpha \mathrm{v} \beta 3$, promotes endothelial cell survival, and induces angiogenesis in vivo. Mol Cell Biol 19:2958-2966

Baffi MO, Moran MA, Serra R (2006) Tgfbr2 regulates the maintenance of boundaries in the axial skeleton. Dev Biol 96:363-374

Ballestrem C, Erez N, Kirchner J, Kam Z, Bershadsky A, Geiger B (2006) Molecular mapping of tyrosine-phosphorylated proteins in focal adhesions using fluorescence resonance energy transfer. J Cell Sci 119:866-875

Bengtsson T, Aszodi A, Nicolae C, Hunziker EB, Lundgren-Åkerlund E, Fässler R (2005) Loss of $\alpha 10 \beta 1$ integrin expression leads to moderate dysfunction of growth plate chondrocytes. J Cell Sci 118:929-936

Brigstock DR (2003) The CCN family: a new stimulus package. J Endocrinol 178:169-175

Camper L, Hellman U, Lundgren-Åkerlund E (1998) Isolation, cloning, and sequence analysis of the integrin subunit $\alpha 10$, a $\beta 1$-associated collagen binding integrin expressed on chondrocytes. J Biol Chem 273:20383-20389

Chen CC, Chen N, Lau LF (2001) The angiogenic factors Cyr61 and connective tissue growth factor induce adhesive signaling in primary human skin fibroblasts. J Biol Chem 276:10443-10452

Chen J, Diacovo TG, Grenache DG, Santoro SA, Zutter MM (2002) The $\alpha 2$ integrin subunit-deficient mouse: a multifaceted phenotype including defects of branching morphogenesis and hemostasis. Am J Pathol 161:337-344

Chen Y, Abraham DJ, Shi-Wen X, Pearson JD, Black CM, Lyons KM, Leask A (2004) CCN2 (connective tissue growth factor) promotes fibroblast adhesion to fibronectin. Mol Biol Cell 15:5635-5646

Chen FH, Thomas AO, Hecht JT, Goldring MB, Lawler J (2005) Cartilage oligomeric matrix protein/thrombospondin 5 supports chondrocyte attachment through interaction with integrins. J Biol Chem 280:32655-32661

Ekblom P, Vestweber D, Kemler R (1986) Cell-matrix interactions and cell adhesion during development. Annu Rev Cell Biol 2:27-47

Ekholm E, Hankenson KD, Uusitalo H, Hiltunen A, Gardner H, Heino J, Penttinen R (2002) Diminished callus size and cartilage synthesis in $\alpha 1 \beta 1$ integrin-deficient mice during bone fracture healing. Am J Pathol 160:1779-1785

Enomoto-Iwamoto M, Iwamoto M, Nakashima K, Mukudai Y, Boettiger D, Pacifici M, Kurisu K, Suzuki F (1997) Involvement of $\alpha 5 \beta 1$ integrin in matrix interactions and proliferation of chondrocytes. J Bone Miner Res 12:1124-1132

Frazier K, Williams S, Kothapalli D, Klapper H, Grotendorst GR (1996) Stimulation of fibroblast cell growth, matrix production, and granulation tissue formation by connective tissue growth factor. J Invest Dermatol 107:404-411

Friedrichsen S, Heuer H, Christ S, Winckler M, Brauer D, Bauer K, Raivich G (2003) CTGF expression during mouse embryonic development. Cell Tissue Res 312:175-188
Gao R, Brigstock DR (2004) Connective tissue growth factor (CCN2) induces adhesion of rat activated hepatic stellate cells by binding of its C-terminal domain to integrin $\alpha \mathrm{v} \beta 3$ and heparan sulfate proteoglycan. J Biol Chem 279:8848-8855

Gao R, Brigstock DR (2005) Connective tissue growth factor (CCN2) in rat pancreatic stellate cell function: integrin $\alpha 5 \beta 1$ as a novel CCN2 receptor. Gastroenterology 129:1019-1030

Gao R, Brigstock DR (2006) A novel integrin $\alpha 5 \beta 1$ binding domain in module 4 of connective tissue growth factor (CCN2/CTGF) promotes adhesion and migration of activated pancreatic stellate cells. Gut 55:856-862

Garciadiego-Cázares D, Rosales C, Katoh M, Chimal-Monroy J (2004) Coordination of chondrocyte differentiation and joint formation by $\alpha 5 \beta 1$ integrin in the developing appendicular skeleton. Development 131:4735-4742

Hamadi A, Bouali M, Dontenwill M, Stoeckel H, Takeda K, Rondé P (2005) Regulation of focal adhesion dynamics and disassembly by phosphorylation of FAK at tyrosine 3. J Cell Sci 118: $4415-4425$

Häusler G, Helmreich M, Marlovits S, Egerbacher M (2002) Integrins and extracellular matrix proteins in the human childhood and adolescent growth plate. Calcif Tissue Int 71:212-218

Holinstat M, Knezevic N, Broman M, Samarel AM, Malik AB, Mehta D (2006) Suppression of RhoA activity by focal adhesion kinaseinduced activation of p190RhoGAP: role in regulation of endothelial permeability. J Biol Chem 281:2296-2305

Holtkötter O, Nieswandt B, Smyth N, Muller W, Hafner M, Schulte V, Krieg T, Eckes B (2002) Integrin $\alpha 2$-deficient mice develop normally, are fertile, but display partially defective platelet interaction with collagen. J Biol Chem 277:10789-10794

Hoshijima M, Hattori T, Inoue M, Araki D, Hanagata H, Miyauchi A, Takigawa M (2006) CT domain of CCN2/CTGF directly interacts with fibronectin and enhances cell adhesion of chondrocytes through integrin $\alpha 5 \beta 1$. FEBS Lett 580:1376-1382

Huang S, Varani J, Chakrabarty S (1994) Control of AKR fibroblast phenotype by fibronectin: regulation of cell-surface fibronectin binding receptor by fibronectin. J Cell Physiol 161: $470-482$

Hurvitz JR, Suwairi WM, Van Hul W, El-Shanti H, Superti-Furga A, Roudier J, Holderbaum D, Pauli RM, Herd JK, Van Hul EV, Rezai-Delui H, Legius E, Le Merrer M, Al-Alami J, Bahabri SA, Warman ML (1999) Mutations in the CCN gene family member WISP3 cause progressive pseudorheumatoid dysplasia. Nat Genet 23:94-98

Hynes RO (2002) Integrins: bidirectional, allosteric signaling machines. Cell 110:673-687

Inoki I, Shiomi T, Hashimoto G, Enomoto H, Nakamura H, Makino K, Ikeda E, Takata S, Kobayashi K, Okada Y (2002) Connective tissue growth factor binds vascular endothelial growth factor (VEGF) and inhibits VEGF-induced angiogenesis. FASEB J 16:219-221

Ivkovic S, Yoon BS, Popoff SN, Safadi FF, Libuda DE, Stephenson RC, Daluiski A, Lyons KM (2003) Connective tissue growth factor coordinates chondrogenesis and angiogenesis during skeletal development. Development 130:2779-2791

Kim SJ, Kim EJ, Kim YH, Hahn SB, Lee JW (2003) The modulation of integrin expression by the extracellular matrix in articular chondrocytes. Yonsei Med J 44:493-501

Kubota S, Takigawa M (2007) Role of CCN2/CTGF/Hes24 in bone growth. Int Rev Cytol 257:1-41

Kubota S, Hattori T, Shimo T, Nakanishi T, Takigawa M (2000) Novel intracellular effects of human connective tissue growth factor expressed in Cos-7 cells. FEBS Lett 474:58-62

Lahiji K, Polotsky A, Hungerford DS, Frondoza CG (2004) Cyclic strain stimulates proliferative capacity, $\alpha 2$ and $\alpha 5$ integrin, gene marker expression by human articular chondrocytes propagated 
on flexible silicone membranes. In Vitro Cell Dev Biol Anim 40:138-142

Larouche K, Leclerc S, Salesse C, Guerin SL (2000) Expression of the $\alpha 5$ integrin subunit gene promoter is positively regulated by the extracellular matrix component fibronectin through the transcription factor Sp1 in corneal epithelial cells in vitro. J Biol Chem 275:39182-39192

Lau LF, Lam S (1999) The CCN family of angiogenic regulators: the integrin connection. Exp Cell Res 248:44-57

Leask A, Abraham DJ (2004) TGF- $\beta$ signaling and the fibrotic response. FASEB J 18:816-827

Lefebvre V, Garofalo S, Zhou G, Metsäranta M, Vuorio E, De Crombrugghe B (1994) Characterization of primary cultures of chondrocytes from type II collagen/ $\beta$-galactosidase transgenic mice. Matrix Biol 14:329-335

Leu SJ, Liu Y, Chen N, Chen CC, Lam SC, Lau LF (2003) Identification of a novel integrin $\alpha 6 \beta 1$ binding site in the angiogenic inducer CCN1 (CYR61). J Biol Chem 278:33801-33808

Loeser RF (2002) Integrins and cell signaling in chondrocytes. Biorheology 39:119-124

Mo FE, Muntean AG, Chen CC, Stolz DB, Watkins SC, Lau LF (2002) CYR61 (CCN1) is essential for placental development and vascular integrity. Mol Cell Biol 22:8709-8720

Nakanishi T, Nishida T, Shimo T, Kobayashi K, Kubo T, Tamatani T, Tezuka K, Takigawa M (2000) Effects of CTGF/Hcs24, a product of a hypertrophic chondrocyte-specific gene, on the proliferation and differentiation of chondrocytes in culture. Endocrinology 141:264-273

Nishida T, Nakanishi T, Asano M, Shimo T, Takigawa M (2000) Effects of CTGF/Hcs24, a hypertrophic chondrocyte-specific gene product, on the proliferation and differentiation of osteoblastic cells in vitro. J Cell Physiol 184:197-206

Nishida T, Kubota S, Nakanishi T, Kuboki T, Yosimichi G, Kondo S, Takigawa M (2002) CTGF/Hcs24, a hypertrophic chondrocytespecific gene product, stimulates proliferation and differentiation, but not hypertrophy of cultured articular chondrocytes. J Cell Physiol 192:55-63

Nishida T, Kubota S, Kojima S, Kuboki T, Nakao K, Kushibiki T, Tabata Y, Takigawa M (2004) Regeneration of defects in articular cartilage in rat knee joints by CCN2 (Connective tissue growth factor). J Bone Miner Res 19:1308-1319

Perbal B (2004) CCN proteins: multifunctional signalling regulators. Lancet 363:62-64

Perbal B, Takigawa M (2005) The CCN family of proteins: an overview. In: Perbal B, Takigawa M (eds.), CCN proteins: a new family of cell growth and differentiation regulators. Imperial College Press, pp. 1-18

Pulai JI, Del Carlo M Jr, Loeser RF (2002) The $\alpha 5 \beta 1$ integrin provides matrix survival signals for normal and osteoarthritic human articular chondrocytes in vitro. Arthritis Rheum 46: $1528-1535$

Rachfal AW, Brigstock DR (2005) Structural and functional properties of CCN proteins. Vitam Horm 70:69-103

Robels E, Gomez TM (2006) Focal adhesion kinase signaling at sites of integrin-mediated adhesion controls axon pathfinding. Nat Neurosci 9:1274-1283
Ruest PJ, Roy S, Shi E, Mernaugh RL, Hanks SK (2000) Phosphospecific antibodies reveal focal adhesion kinase activation loop phosphorylation in nascent and mature focal adhesions and requirement for the autophosphorylation site. Cell Growth Differ 11:41-48

Salter DM, Millward-Sadler SJ, Nuki G, Wright MO (2001) Integrininterleukin-4 mechanotransduction pathways in human chondrocytes. Clin Orthop Relat Res 391:S49-S60

Sawada Y, Tamada M, Dubin-Thaler BJ, Cherniavskaya O, Sakai R, Tanaka S, Sheetz MP (2006) Force sensing by mechanical extension of the Src family kinase substrate p130Cas. Cell 127:1015-1026

Schlaepfer DD, Hauck CR, Sieg DJ (1999) Signaling through focal adhesion kinase. Prog Biophys Mol Biol 71:435-478

Serra R, Johnson M, Filavaroff EH, LaBorde J, Sheehan DM, Derynck R, Moses HL (1997) Expression of a truncated, kinase-defective TGF- $\beta$ type II receptor in mouse skeletal tissue promotes terminal chondrocyte differentiation and osteoarthritis. J Cell Biol 139:541-552

Shimo T, Nakanishi T, Nishida T, Asano M, Kanyama M, Kuboki T, Tamatani T, Tezuka K, Takemura M, Matsumura T, Takigawa M (1999) Connective tissue growth factor induces the proliferation, migration, and tube formation of vascular endothelial cells in vitro, and angiogenesis in vivo. J Biochem 126:137-145

Takigawa M (2003) CTGF/Hcs24 as a multifunctional growth factor for fibroblasts, chondrocytes and vascular endothelial cells. Drug News Perspect 16:11-21

Tong ZY, Brigstock DR (2006) Intrinsic biological activity of the thrombospondin structural homology repeat in connective tissue growth factor. J Endocrinol 188:R1-R8

Weston BS, Wahab NA, Mason RM (2003) CTGF mediates TGF- $\beta$ induced fibronectin matrix deposition by upregulating active $\alpha 5 \beta 1$ integrin in human mesangial cells. J Am Soc Nephrol 14:601-610

Wong M, Kireeva ML, Kolesnikova TV, Lau LF (1997) Cyr61, product of a growth factor-inducible immediate-early gene, regulates chondrogenesis in mouse limb bud mesenchymal cells. Dev Biol 192:492-508

Yoon BS, Ovchinnikov DA, Yoshii I, Mishina Y, Behringer RR, Lyons KM (2005) Bmprla and Bmprlb have overlapping functions and are essential for chondrogenesis in vivo. Proc Natl Acad Sci U S A 102:5062-5067

Yoon BS, Pogue R, Ovchinnikov DA, Yoshii I, Mishina Y, Behringer RR, Lyons KM (2006) BMPs regulate multiple aspects of growth-plate chondrogenesis through opposing actions on FGF pathways. Development 133:4667-4678

Zaidel-Bar R, Milo R, Kam Z, Geiger B (2007) A paxillin tyrosine phosphorylation switch regulates the assembly and form of cellmatrix adhesions. J Cell Sci 120:137-148

Zelzer EW, McLean W, Ng YS, Fukai N, Reginato AM, Lovejoy S, D'Amore PA, Olsen BR (2002) Skeletal defects in VEGF120/ 120 mice reveal multiple roles for VEGF in skeletogenesis. Development 129:1893-1904

Zemmyo M, Meharra EJ, Kühn K, Creighton-Achermann L, Lotz M (2003) Accelerated, aging-dependent development of osteoarthritis in $\alpha 1$ integrin-deficient mice. Arthritis Rheum 48:2873-2880 